\title{
Między Zachodem a Wschodem, t. 6: Organizacja władz miejskich na obszarze Pierwszej Rzeczypospolitej i na Śląsku w XIII-XVIII w., red. Mateusz Goliński, Krzysztof Mikulski, Wydawnictuo Adam Marszałek, Toruń 2013, ss. 348
}

(c) (1) $\Theta$

http://dx.doi.org/10.12775/KLIO.2014.027

$\mathrm{O}$ pracowanie zbiorowe poświęcone ustrojowi kilkunastu wybranych miast w średniowieczu i epoce nowożytnej może być interesującą lekturą nie tylko dla historyków miast, zawiera bowiem ciekawe spostrzeżenia z zakresu historii prawa, struktur i stosunków społecznych na ogromnym i zróżnicowanym pod wieloma względami obszarze. Dwa pierwsze teksty dotyczą organizacji władz miejskich i ustroju Chełmna w średniowieczu (pióra Romana Czai) oraz w XVI-XVIII wieku (autorstwa Marka Zielińskiego). Roman Czaja poddał analizie przywilej lokacyjny miasta, następnie przedstawił kształtowanie się ustroju „radzieckiego”, czyli działającego z przewagą rady nad pozostałymi instytucjami komunalnymi, wreszcie genezę, liczebność rady i podział funkcji wewnątrz tego organu. Wspomniał nadto o ceremonii wyboru rady. Osobny fragment dotyczy działalności ław sądowych. Zabrakło natomiast charakterystyki kancelarii i personelu pomocniczego. Natomiast Marek Zieliński, po uwagach wstępnych tyczących się zmian po przejściu miasta pod władzę biskupów chełmińskich w 1505 roku, omówił kolejno radę miejską, urząd ławniczy i trzeci ordynek. Następnie przedstawił zasady wyboru władz miejskich (kiera) i rozliczania pieniędzy publicznych, wreszcie kompetencje urzędów obsadzanych indywidualnie (burmistrz, kamlarz i inni, ale bez personelu kancelaryjnego).

Autorem kolejnego tekstu, poświęconego organizacji władz miejskich Elbląga w średniowieczu jest Roman Czaja. Wychodząc od analizy przywileju lokacyjnego z 1246 roku, autor przedstawił genezę ustroju miasta, zasadnie postrzegając rozwiązania ustrojowe jako wypadkową pomiędzy zabiegami mieszczan o pełną autonomię, a dążeniem władcy terytorial- 
nego do zachowania wpływu na sądownictwo i administrację w mieście. Następnie scharakteryzował kolejne instytucje: sołectwo dziedziczne, radę, sądy miejskie a także kancelarię i niższe urzędy. Osobne miejsce poświęcił ustrojowi i organizacji władz Nowego Miasta Elbląga.

Kolejne artykuły dotyczą miast śląskich. Ewa Wółkiewicz omówiła władze miejskie w Nysie w XIII-XVII wieku, zaczynając od dosyć obszernego przedstawienia historii miasta. Następny fragment został poświęcony radzie miejskiej, jej początkom, elekcji i liczebności, wreszcie funkcjom poszczególnych rajców i kompetencjom tego organu. W drugiej części artykułu autorka przedstawiła ławę sądową, urzędników Starego Miasta i przedmieść. Dosyć skrótowo potraktowała niższy personel urzędniczy. Tekst kończą uwagi o wójtostwie nyskim.

Następny artykuł, pióra Mateusza Golińskiego, został poświęcony władzom Świdnicy od XIII do XVIII wieku. Tu trzeba podkreślić, że autor najbardziej konsekwentnie dostosował tekst do przyjętych założeń, przedstawionych przezeń (jako redaktora książki) we Wstępie. Zgodnie z założeniem autorzy winni byli bowiem poddać analizie następujące zagadnienia: 1. Lokacja i typ prawa miejskiego; 2. Rada miejska, w tym osobno kształtowanie się ustroju radzieckiego, funkcje w obrębie rady i jej organy pomocnicze; 3. Wójtostwo; 4. Ława sądowa; 5. Rodzaje sądów; 6. Reprezentacja pospólstwa; 7. Kancelaria; 8. Syndyk miejski; 9. Inni urzędnicy; 10 służby miejskie. Taki układ treści miał w założeniu ułatwić prowadzenie badań porównawczych w przyszłości, z czym należy się w pełni zgodzić. Podobnie konsekwentny był inny wrocławski historyk, Stanisław Jujeczka, w tekście poświęconym Legnicy. Czytelnik znajdzie tu szczegółowe informacje o zmianach ustrojowych od XIII wieku do 1740 roku a także o urzędach, przy czym najwięcej o tamtejszej radzie.

Zagłębiając się w lekturę recenzowanej pracy, przenosimy się na pogranicze Śląska, Małopolski i Wielkopolski, do Wielunia. Ustrojowi tego miasta przyjrzeli się łódzcy historycy, Tadeusz Grabarczyk i Tadeusz Nowak, koncentrując rozważania na uprawnieniach rady oraz na zarządzaniu finansami miejskimi, ale nie zaniedbując pozostałych instytucji ustrojowych (wójtostwo, ława) i służby miejskiej. Kolejny tekst, autorstwa Janusza Grabowskiego, dotyczy szczegółowo i ze znawstwem przedstawionej historii ustroju oraz organizacji władz dwóch funkcjonujących obok siebie 
miast - Starej i Nowej Warszawy - do końca XVIII wieku. Autor poświęcił także nieco uwagi reformom ustrojowym przeprowadzonym $\mathrm{w}$ dobie Sejmu Czteroletniego.

Z Warszawy redaktorzy przenoszą czytelnika znów na południe, na Ruś; najpierw do Lwowa. Ustrojem tego miasta zajął się ukraiński historyk, Myron Kapral. Pozostaje on konsekwentnie zwolennikiem słabo uzasadnionej źródłowo hipotezy o istnieniu gminy miejskiej we Lwowie przed 1340 rokiem. Następnie omówił podstawowe instytucje ustrojowe Lwowa, a jako jeden z nielicznych autorów przybliżył w szczegółach rodzaje sądów miejskich. Poświęcił też wiele uwagi samorządowi Ormian i Rusinów w tym wieloetnicznym mieście nad Pełtwią. Podobny ustrojowo do Lwowa był pobliski Przemyśl, którego władze w okresie przedrozbiorowym przedstawiła Ewa Grin-Piszczek, uwzględniając wszystkie ważniejsze kwestie, zaplanowane we wspomnianym już katalogu pytań badawczych .

W dalszej części książki pozostajemy już w kręgu miast na wschodnich krańcach Rzeczypospolitej. Natalia Biłous podjęła się zbadania władz miasta Kijowa w XVI i pierwszej połowie XVII wieku. Historyczka związana z Instytutem Historii Ukraińskiej Akademii Nauk zasadniczo zachowała przyjęty model postępowania badawczego, przedstawiając na szerokim tle porównawczym i szczegółowo kompetencje poszczególnych organów miejskich, ich wzajemne zależności i praktykę administracyjną w tym mieście. Kolejny tekst napisał Vasil Varonin, a dotyczy on organizacji władz miejskich Połocka od końca XIV do połowy XVI wieku, czyli w okresie ewolucji od „prawa ruskiego” do magdeburskiego. Widoczne tu były wpływy Wschodu oraz znaczna odmienność od modelu ustrojowego miasta w Koronie. Tę odmienność dostrzec można jeszcze wyraźniej w ostatnim artykule, pióra Maksima Makaraua, poświęconym miastom powiatu witebskiego w XVI i pierwszej połowie XVII wieku.

W podsumowaniu należy zaznaczyć walor informacyjny książki. Chociaż dobór miast trzeba traktować jako studium przypadków, to warto podkreślić, że publikowane teksty dotyczą ośrodków miejskich położonych $\mathrm{w}$ różnych regionach historycznych, zawierają szereg oryginalnych, nieupowszechnionych dotąd w literaturze informacji i spostrzeżeń, które potwierdzają różnorodność ustrojową miast w Rzeczypospolitej i konieczność dalszych badań nad tą problematyką. Nie udało się wprawdzie osią- 
gnąć w pełni zakładanego celu i poszczególne teksty różnią się między sobą układem treści, zakresem chronologicznym itd., ale w pracach zbiorowych ciągle jeszcze niezmiernie rzadko udaje się w Polsce mobilizacja autorów do precyzyjnego wykonania podjętego zadania. Utrudnia to realizację prac zespołowych, które przecież stają się priorytetem w naukach historycznych. W moim przekonaniu recenzowana książka stanowi pierwszy krok w nowych badaniach zespołowych nad ustrojem miast. Opublikowane teksty są obiecujące i poświadczają, że inicjatywy tego typu otwierają nowe możliwości badawcze i powinny być kontynuowane.

Zdzistaw Noga (Kraków) 